\title{
Neuronal-astrocytic network of the mouse hippocampus
}

\section{Hrvoje Jakovac}

Department of Physiology and Immunology, Medical Faculty, University of Rijeka, Brace Branchetta 20, 51000 Rijeka, Croatia

The figures show a microscopic immunofluorescent images of mouse hippocamal tissue, labeled with antibodies against specific neuronal marker neurofilament $\mathrm{H}$ (red) and astrocytic marker glial fibrillary acidic protein (GFAP, green). Astrocytes are particularly abundant in the periventricular and perivascular areas, where they are

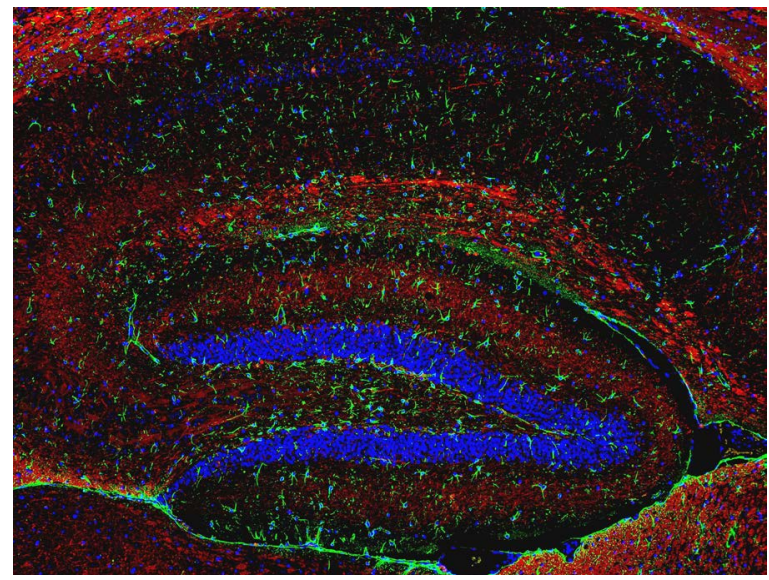

Figure A

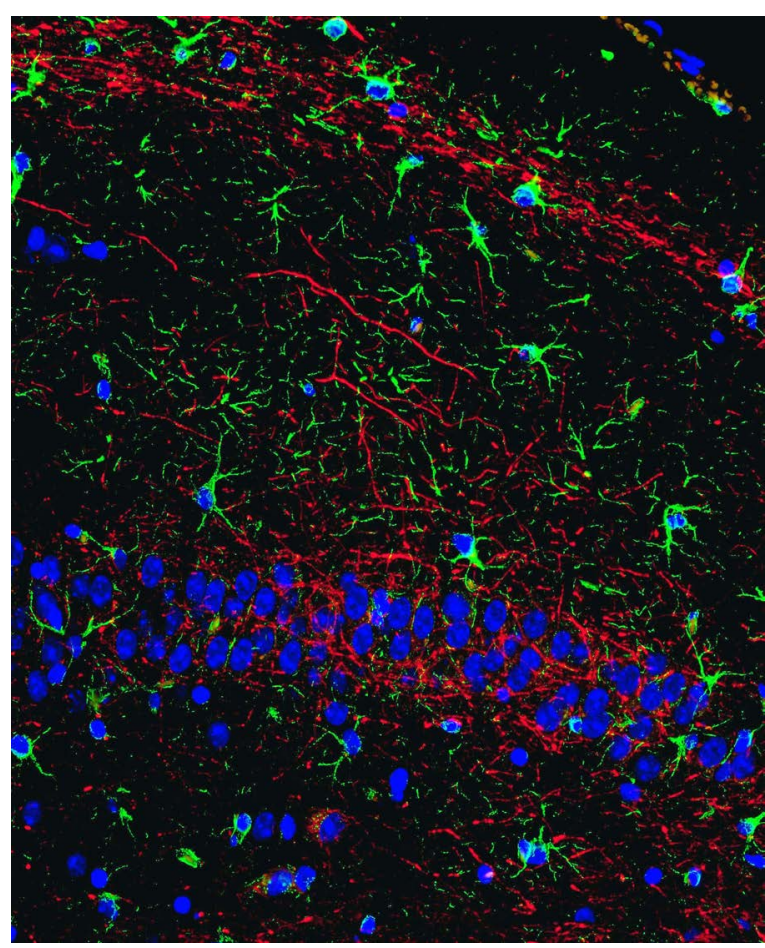

Figure B

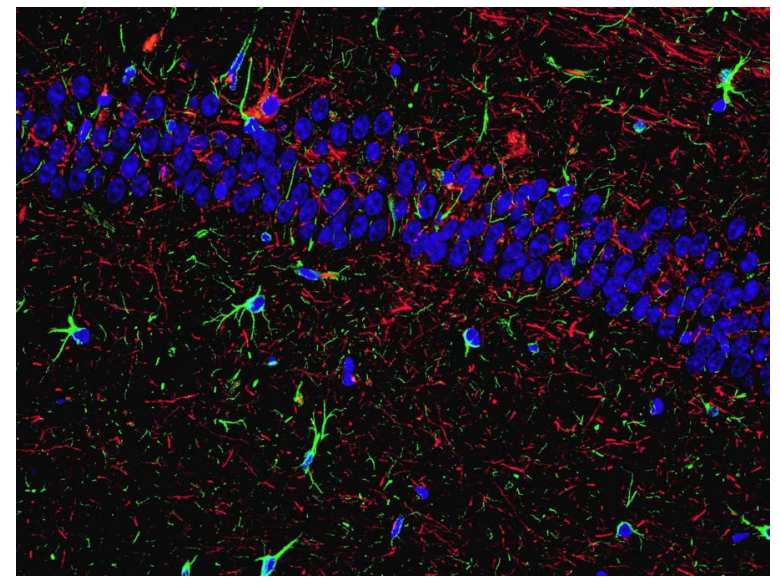

Figure C

one of the key components that form a blood-brain barrier (figure a; magnification $x$ 100). Interweaving of axons and astrocytic processes can be seen at larger magnification (figures $b$ and $c$; magnification $\mathrm{x}$ 1000). Recent researches clearly show active regulatory role of astrocytes in various homeostatic and adaptive processes, such as neuronal firing, neurotransmitter metabolism, synaptogenesis and neuroplasticity [1].

\section{References}

1. Blanco-Suárez E, Caldwell AL, Allen NJ (2017) Role of astrocyte-synapse interactions in CNS disorders. J Physiol 595: 1903-1916. [Crossref]

Copyright: (C2018 Jakovac H. This is an open-access article distributed under the terms of the Creative Commons Attribution License, which permits unrestricted use, distribution, and reproduction in any medium, provided the original author and source are credited.

${ }^{\star}$ Correspondence to: Jakovac H, Department of Physiology and Immunology, Medical Faculty, University of Rijeka, Brace Branchetta 20, 51000 Rijeka, Croatia, E-mail: hrvoje.jakovac@medri.uniri.hr

Received: March 20, 2018; Accepted: April 17, 2018; Published: April 19, 2018 